\title{
Van İli Atıksu Arıtma Tesisleri İşletme Sorunları ve Çözüm Önerileri
}

\author{
Ahmet DURAK ${ }^{1}$, Ayşe ÖZGÜVEN²* ${ }^{*}$ Ayşegül DEMİR YETİ̧̧ ${ }^{3}$ \\ ${ }^{1}$ VASKI Genel Müdürlü̆̆̈̈ Arıtma Tesisleri Daire Başkanlı̆̆ Atıksu Arıtma Şube Müdürlüğ̈̈ \\ ${ }^{2}$ Van Yüzüncü Yll Üniversitesi Mühendislik Fakültesi Çevre Mühendisliği Bölümü \\ ${ }^{3}$ Bitlis Eren Üniversitesi Sağllk Bilimleri MYO, Tıbbi Hizmetler ve Teknikler Bölümü, Çevre Sağllğ Programı \\ (ORCID: 0000-0003-1497-8387) (ORCID: 0000-0003-1071-2813) (ORCID: 0000-0003-4745-2445)
}

\begin{abstract}
$\ddot{O} \mathbf{z}$
Kullanılmış suların çevreye olan zararlarını azaltmak ve su kaynaklarımızın devamlılığını sağlamak için atıksu arıtma tesisleri kurulmaktadır. Evsel nitelikli atıksular farklı proses ve teknolojiler kullanılarak arıtılmaktadır. Günümüzde evsel atıksu arıtımında kullanılan en yaygın sistemler stabilizasyon havuzları, damlatmalı filtre, aktif çamur ve aneorobik arıtma gibi biyolojik sistemlerdir. Karakterizasyon bakımından farklı özelliğe sahip olan evsel atıksular için mevcut proseslerin optimize edilmesi veya bölge koşulları dikkate alınarak uygun arıtma teknolojilerinin kullanılması önem arz etmektedir. Fizibilite çalışmalarının yetersizliği, tip proje uygulamaları ve proje hataları ile birlikte, mekanik, elektrik, inşaat kaynaklı sorunlar, atıksu arıtma tesisleri problemlerini oluşturmaktadır. Çıkış suyunda istenilen kalitenin elde edilmesi ve tesiste işletme maliyetlerinin azaltılması için projelendirme, inşaat ve işletme aşamalarında yapılan hatalar en aza indirilmelidir. Bu çalışmada Van iline hizmet eden ve işletmede olan 6 adet atıksu arıtma tesisinin (İskele, Edremit, Gevaş, Başkale, Çelebibağ ve Gölağzı) genel özellikleri de dikkate alınarak ilk kez il özelinde tesis bazlı olarak işletme problemleri araştırılmış ve bunlara yönelik çözüm önerileri değerlendirilmiştir.
\end{abstract}

Anahtar Kelimeler: Atıksu arıtımı, çözüm önerileri, işletme problemleri, Van.

\section{Operational Problems and Solution Suggestions of Van Province Wastewater Treatment Plants}

\begin{abstract}
Wastewater treatment plants are established in order to reduce the damage of wastewater to the environment and to ensure the continuity of water resources. Domestic wastewater is treated using different processes and technologies. The most common systems currently used in domestic wastewater treatment are biological systems such as stabilization pools, trickling filters, activated sludge and anaerobic treatment. It is important to optimize the existing processes for domestic wastewater, which has different characteristics in terms of characterization, or to use appropriate treatment technologies, taking into account the regional conditions. Inadequate feasibility studies, type project applications and project errors, together with mechanical, electrical, construction-related problems, constitute the problems of wastewater treatment plants. In order to obtain the desired quality in the effluent and to reduce the operating costs in the facility, the mistakes made during the projecting, construction and operation stages should be minimized. In this study, considering the general characteristics of 6 wastewater treatment plants (Iskele, Edremit, Gevaş, Başkale, Çelebibağ and Gölağzı) that are in operation and serving the province of Van, for the first time, plant-based operational problems were investigated and solution proposals for them were evaluated.
\end{abstract}

Keywords: Wastewater treatment, solution proposals, operational problems, Van

\section{Giriş}

Nüfus artışı, teknolojinin gelişmesi ve hayat standartlarının yükselmesi gibi nedenlerle dünyada ve ülkemizde atıksu üretimi artmıştır [1-3]. Üretilen bu atıksuların alıcı ortamlara kontrolsüz bir şekilde

*Sorumlu yazar: ayseozguven@yyu.edu.tr

Geliş Tarihi: 01.07.2021, Kabul Tarihi: 07.10.2021 
verilmesi büyük çevre sorunlarına yol açmaktadır [4-6]. Toprak ve su kaynaklarımızın kirlenmesini önlemek ve çevre sağlığını korumak için evsel atıksuların arıtılmasında fiziksel ve kimyasal proseslerden daha çok biyolojik arıtım prosesleri tercih edilmektedir [7-8]. Atıksu arıtma tesislerinde (AAT) kullanılan prosesler, atıksularda bulunan patojen (hastalık yapıcı) mikroorganizmaların olumsuz etkilerini en aza indirecek şekilde tasarlanmalıdır. [9]. Evsel atıksuların arıtılmasında yaygın olarak kullanılan biyolojik prosesler arasında; aerobik oksidasyon, nitrifikasyon, denitrifikasyon ve fosfor giderimi gibi prosesler yer almaktadır. Evsel atıksulardan karbon, fosfor ve azot gideriminin ekonomik olması ve daha az atık çamur oluşumu gibi nedenlerden dolayı aktif çamur sistemleri kullanılmaktadır [10].

AAT'lerinin tasarımı, inşaası ve işletilmesinin temel amacı, atıksu kalitesinin iyileştirilerek mevzuatla belirlenen parametrelere ait değerlerin karşılanmasını sağlamaktır. İşletme faaliyetleri, AAT'nin istenen kalitede atıksu üretmesi ve mevzuatta verilen değerleri sağlaması için yeterli olmalıdır. AAT bakım faaliyetleri ise, sürdürülebilir işletme hedeflerine ulaşmak için ekipmanın düzenli ve verimli çalışmasını sağlamaya yönelik faaliyetler olmalıdır. Örneğin düşük sermaye maliyetine sahip küçük ve basit bir arıtma tesisi, yüksek işletme giderlerine sahip olabilir. Bu nedenle alternatif bir teknolojiye kıyasla toplam maliyeti daha yüksektir. Arıtma tesisinin tasarım kriterleri göz önünde bulundurularak daha iyi yönetilmesi ve işletilmesi için izleme ve bakım faaliyetleri yürütülmeli ve arıtma tesisinin bakımını yapan işletmeci, bu ünitelerin arızalanması durumunda ünite proseslerinden haberdar olmalıdır [11]. Az gelişmiş ve gelişmekte olan ülkelerdeki AAT'ler, genellikle su dağıtım süreçleri esnasında yüksek işletme maliyetlerini karşılamak için yeterli bütçeyi sağlamada eksik kalmakta ve işletme ve bakımda bazı sorunlarla karşı karşıya kalmaktadır. Bu nedenle, operasyonel işgücünü sağlamak ve etkili bir işletme performansı için atıksu arıtma tesisinden sorumlu yönetici personelin tesis performansını hızlı bir şekilde gözden geçirmesi gerekmektedir [12]. Çünkü AAT'ler farklı fiziksel, kimyasal ve biyolojik arıtma mekanizmalarına sahip değişken debi ve yükler alan karmaşık sistemlerdir [13]. Bu nedenle işletme sorunlarını en aza indirmek için Su Kirliliği Kontrol Yönetmeliğin'de belirtilen deşarj suyu kalite standartlarını karşılamaları gerekmektedir [14-15]. Su kalite parametrelerinin kontrolü, arıtma tesisi giriş ve çıkış sularının sürekli analizlerinin yapılması, atıksu debisinin kontrolü ve mekanik ekipmanların kontrollerinin ve bakımlarının düzenli aralıklarla yapılması sorunsuz bir işletme için gereklidir [16]. Mekanik ekipmanların bakımı, yağlanması, eskimiş parçaların yenisiyle değiştirilmesi ve yedek parçaların sağlanması gerekmektedir. Ayrıca arıtma tesislerinin sorunsuz bir şekilde işletilmesi için eğitim programları düzenlenmeli, toplantılar yapılmalı ve yeterli bilgi ve deneyime sahip kalifiye eleman yetiştirilmelidir. Su kalitesini tehdit eden operasyonel problemler meydana geldiğinde, herhangi bir sorunu azaltmaya veya hafifletmeye yardımc1 olmak için ilgili tüm tarafları bilgilendirmek gereklidir.

Operasyonel problemler genellikle atıksu arıtma performansını ve atıksu çıkış kalitesini etkileyecek olaylar olarak tanımlanır. Potansiyel operasyonel problemleri mümkün olduğunca azaltmak için planlama ve tasarım sırasında bu problemleri önceden tahmin etmek gereklidir. Bunun için çoklu tasarımlar ve güvenilir ekipman kullanmak, iyi eğitimli ve motive olmuş personel sağlamak önemlidir. İyi tasarlanmış ve bakımı sürekli yapılan arıtma tesisleri aşırı yüklenmedikleri sürece normal koşullar altında iyi derecede arıtma performansı sağlayacaktır. Arıtma tesisinin performansında önem arz eden diğer bir husus atıksu kalite parametreleridir. Bu parametreler AAT'nin sorunsuz olarak işletilmesinde son derece önemlidir. Örneğin, bir arıtma tesisi çıkış suyunun $70 \mathrm{mg} / \mathrm{L}-90 \mathrm{mg} / \mathrm{L}$ 'lik KOİ konsantrasyonu, bir tesiste kararlı performansı temsil edebilirken bir başka tesiste $30 \mathrm{mg} / \mathrm{L}-50 \mathrm{mg} / \mathrm{L}$ arasında bulunan KOİ değerleri bu tesis için kararlı performansı temsil edebilir. Atıksuyun tipik KOİ konsantrasyonu, öncelikle giriş suyu bileşimine bağlıdır [17]. Arıtma tesisi performansının kontrolü için gerekli olan parametrelerin analizi yapılmalı ve peryodik olarak izlenmelidir.

Bu çalışma il özelinde olmak koşuluyla Van İli'ne hizmet eden ve işletmede olan atıksu arıtma tesisleri ile ilgili işletme sorunları ve tesislere ait genel sorunların detaylarını içermektedir. Bununla birlikte incelenen 6 atıksu arıtma tesisi (İskele, Edremit, Gevaş, Başkale, Çelebibağ ve Gölağzı atıksu arıtma tesisleri) için bu sorunlara dair detaylı çözüm önerileri detaylarıyla birlikte sunulmuştur. Ayrıca mevcut çalışma il bazında birden fazla tesise ait sorunları ve çözüm önerilerini detaylarıyla birlikte sunması bakımından bir ilk olma özelliği taşımaktadır. 


\section{Materyal ve Metod}

Van İli dünya üzerinde, $42^{\circ} 40^{\prime}-44^{\circ} 30^{\prime}$ doğu boylamları ile $37^{\circ} 43^{\prime}-39^{\circ} 26^{\prime}$ kuzey enlemleri arasındadır. Türkiye üzerinde ise Doğu Anadolu Bölgesinin Yukarı Murat-Van Bölümündeki Van Gölü kapalı havzasındadır. Van ili Doğu Anadolu Bölgesinin volkanik dağlarla kaplı çukur kesiminde bulunan Van Gölü' nün doğu kıyısına 5 km uzaklıkta çok az meyilli bir arazi üzerine kurulmuştur. Bitlis ve Van illeri sınırında yer alan Nemrut Dağı'nın volkanik patlaması sonrasında kalan kraterde su birikmesiyle oluşan volkanik bir göldür [18] Van Gölü dünyanın en büyük sodalı gölüdür ve ayrıca tuzlu su özelliği de bulunmaktadır [19]. Rakım yüksekliği yaklaşık 1725 m'dir. Gölün yüzölçümü 3764 km² $^{2}$ dir [20]. Van Gölü kapalı havzası, Kentsel Atıksu Arıtımı Yönetmeliği-Hassas ve Az Hassas Su Alanları Tebliğinde belirtilen beş hassas havzadan biridir. Bu havzanın kapalı havza olması ve dolayısıyla dışarıya herhangi bir akışının olmaması kirlenme potansiyelini arttırmaktadır. Havzanın kirlenmesindeki başlıca etkenler göl çevresindeki yerleşimlerden gelen atıksuların yeterli arıtma olmadan alıcı ortama deşarj edilmesidir [21].

Van Büyükşehir Belediyesi VASKİ Genel Müdürlügü’nce yürütülen çalışmalar kapsamında atıksu kaynaklı kirliliğin önüne geçilmesi amacıyla bazı ilçelerde mevcut olan atıksu arıtma tesislerinin işletim çalışmaları yapılmaktadır. Van ilinin merkez ilçeleri olan İpekyolu ve Tuşba'nın tüm atıksuları, Edremit ilçesine ait atıksuların ise bir bölümü Tuşba ilçesinde bulunan İskele Atıksu Arıtma Tesisi'ne verilmektedir. Bunun yanında Başkale, Edremit, Gevaş ve Erciş ilçesinde Çelebibağı ve Gölağzı mahallelerinde de ileri biyolojik atıksu arıtma tesisleri bulunmakta ve aktif olarak işletilmektedir. $\mathrm{Bu}$ çalışmada tesisler hakkında birtakım bilgilere mevcut ve yenilenmiş proje dosyalarından ulaşılmıştır. Ayrıca tesislerdeki sorunlar ve bunlara dair çözüm önerileri hakkında bilgiler için tesis özelinde uzun süreli yapılan gözlemlerle elde edilen bilgilerden faydalanılmıştır. Van İli Evsel Atıksu Arıtma tesislerinin coğrafik konumu Şekil 1'de sunulmuş olup, işletmede olan tesislere ait bilgiler ise Tablo 1 'de gösterilmektedir.

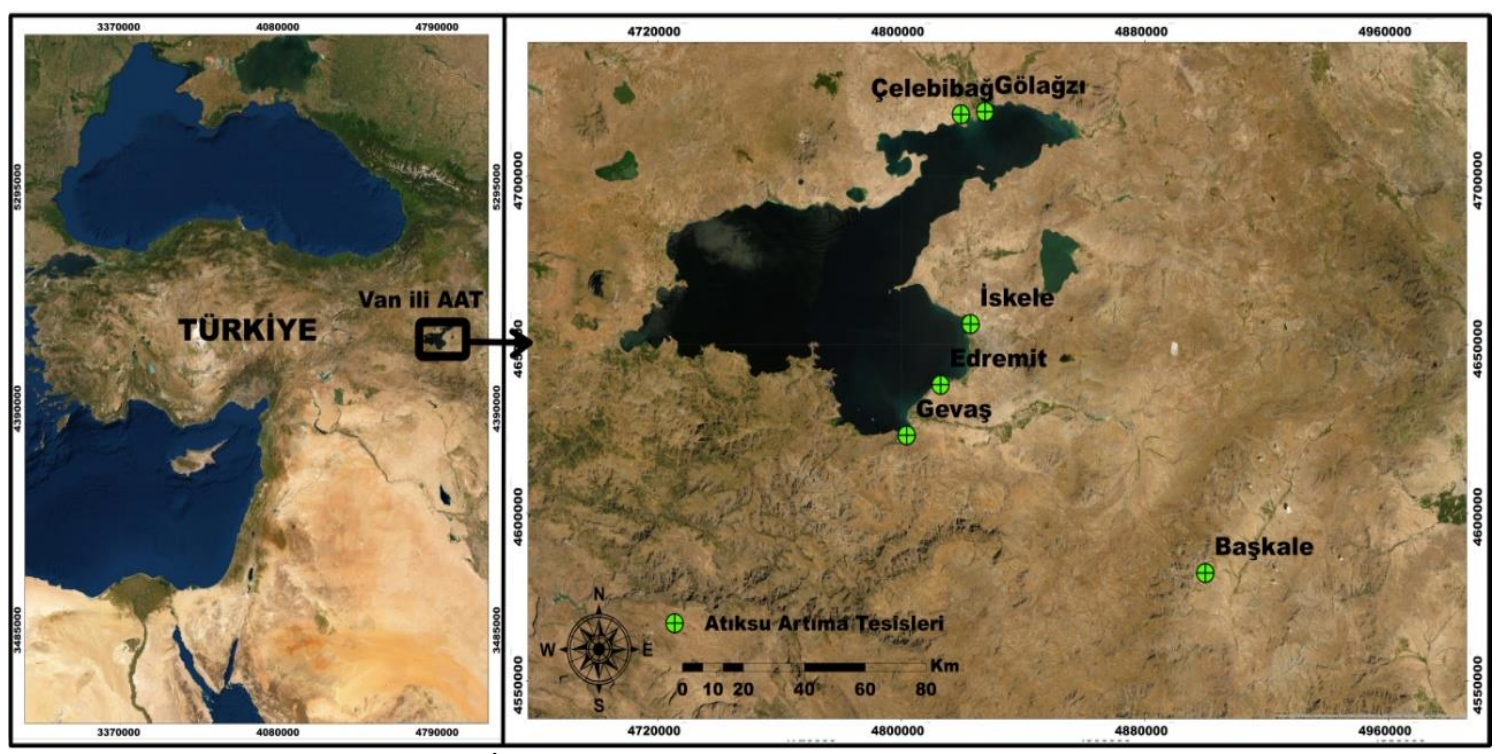

Şekil 1. Van İli Evsel Atıksu Arıtma tesislerinin coğrafik konumu 
Tablo 1. Van İli evsel atıksu arıtma tesislerine ait genel bilgiler

\begin{tabular}{|c|c|c|c|c|c|c|c|}
\hline \multirow[b]{2}{*}{ İlçe } & \multirow{2}{*}{$\begin{array}{l}\text { AAT } \\
\text { Adı }\end{array}$} & \multirow{2}{*}{$\begin{array}{l}\text { Eş } \\
\text { Değer } \\
\text { Nüfus } \\
\text { (kişi) } \\
\end{array}$} & \multirow{2}{*}{$\begin{array}{l}\text { Kapasite } \\
\text { max.debi } \\
\left(\mathbf{m}^{3} / \text { gün}\right)\end{array}$} & \multirow{2}{*}{$\begin{array}{c}\text { Arıtma } \\
\text { Türü }\end{array}$} & \multirow{2}{*}{$\begin{array}{c}\text { Alıcı } \\
\text { Ortam }\end{array}$} & \multicolumn{2}{|c|}{ Koordinat } \\
\hline & & & & & & $\begin{array}{c}\mathbf{X} \\
(\text { Enlem })\end{array}$ & $\begin{array}{c}\mathbf{Y} \\
\text { (Boylam) }\end{array}$ \\
\hline Merkez & $\begin{array}{l}\text { İskele } \\
\text { A.A.T. }\end{array}$ & 320.000 & 103.680 & $\begin{array}{l}\text { Biyolojik arıtma } \\
\text { (Klasik aktif çamur) }\end{array}$ & $\begin{array}{l}\text { Van } \\
\text { Gölü }\end{array}$ & 353887 & 4267225 \\
\hline Edremit & $\begin{array}{l}\text { Edremit } \\
\text { A.A.T. }\end{array}$ & 100.000 & 21.840 & $\begin{array}{l}\text { İleri biyolojik } \\
\text { arıtma (Uzun } \\
\text { havalandırmalı aktif } \\
\text { çamur) }\end{array}$ & $\begin{array}{l}\text { Van } \\
\text { Gölü }\end{array}$ & 345904 & 4253273 \\
\hline Gevaş & $\begin{array}{l}\text { Gevaş } \\
\text { A.A.T. }\end{array}$ & 22.000 & $7.607,00$ & $\begin{array}{l}\text { İleri biyolojik } \\
\text { arıtma (Uzun } \\
\text { havalandırmalı aktif } \\
\text { çamur) }\end{array}$ & $\begin{array}{l}\text { Van } \\
\text { Gölü }\end{array}$ & 336948 & 4241694 \\
\hline Başkale & $\begin{array}{l}\text { Başkale } \\
\text { A.A.T. }\end{array}$ & 21.000 & $4.442,24$ & $\begin{array}{l}\text { İleri biyolojik } \\
\text { arıtma (Uzun } \\
\text { havalandırmalı aktif } \\
\text { çamur) }\end{array}$ & $\begin{array}{l}\text { Değir } \\
\text { Dere }\end{array}$ & 413621 & 4208443 \\
\hline Erciş & $\begin{array}{l}\text { Çelebibă̆ } \\
\text { A.A.T. }\end{array}$ & 40.000 & $4.361,52$ & $\begin{array}{l}\text { İleri biyolojik } \\
\text { arıtma (Uzun } \\
\text { havalandırmalı aktif } \\
\text { çamur) }\end{array}$ & $\begin{array}{l}\text { Van } \\
\text { Gölü }\end{array}$ & 352329 & 4315704 \\
\hline Erciş & $\begin{array}{l}\text { Gölağzı } \\
\text { A.A.T. }\end{array}$ & 205.000 & $72.372,00$ & $\begin{array}{l}\text { İleri biyolojik arıtma } \\
\text { (Uzun } \\
\text { havalandırmalı aktif } \\
\text { çamur) }\end{array}$ & Van Gölü & 358494 & 4316250 \\
\hline
\end{tabular}

\section{1. İskele Atıksu Arıtma Tesisi}

İskele AAT projesi 1988 yılında yapılmış ve inşaası 1992'de tamamlanarak hizmete alınmıştır. 320.000 eşdeğer nüfusa hizmet vermek üzere inşa edilen ve $\mathrm{Q}_{\max }=1200 \mathrm{~L} / \mathrm{sn}$ debiye sahip İskele AAT klasik aktif çamur prosesi uygulanan bir biyolojik arıtma tesisidir. Izgaralardan sonra, atıksu, paralel olarak devreye alınan 3 adet havalandırmalı kum tutucuya (uzunluk: 28,5 m; genişlik: 2,2 m; derinlik: $3 \mathrm{~m}$; toplam hacim: $414 \mathrm{~m}^{3}$ ) doğru akmaktadır. Her bir kum tutucunun tabanına çökelen kum, hareketli bir köprüye monte edilmiş olan sıyırıcı ile kum tutucu membasında yer alan kum haznesine ulaşmaktadır. Her bir arıtma ünitesinde, birbirine paralel iki adet havalandırma havuzu bulunmaktadır; her birinin hacmi 2.600 $\mathrm{m}^{3}$ ve derinliği 4,0 metredir. Toplam havalandırma havuzu hacmi ise $20.800 \mathrm{~m}^{3}$ 'dür. Aktif çamurun arıtılmış atık sudan ayrılması için her ünitede ikişer adet dairesel yatay akışlı son çökeltme havuzu (her birinin çapı: $36 \mathrm{~m}$, derinliği 3,03 m, yüzey alanı: 1,011 m²) bulunmaktadır. Son çökeltme havuzlarından sonra atıksu üç adet cazibeli yoğunlaştırıcıya ulaşır. Dairesel olan yoğunlaştırıcıların her birinin çap 12 $\mathrm{m}$, yüzey alanı $113 \mathrm{~m}^{2}$ ve hacmi $452 \mathrm{~m}^{3}$ ' dür. Yoğunlaştırılan stabilize çamur, 4 adet bant filtre pres ile mekanik olarak susuzlaştırılabilmektedir. Filtre preslerin her biri $15 \mathrm{~m}^{3} / \mathrm{saat}$ arıtma kapasitesine sahip olup yoğun çamur pompaları ile beslenmektedir. Alternatif olarak yoğun çamur, doğrudan çamur kurutma yataklarına pompalanmaktadır. Her birinin yüzey alan $300 \mathrm{~m}^{2}$ olan (toplam yüzey alanı: 16.800 $\mathrm{m}^{2}$ ) çamur kurutma yatakları atıksu artıma tesisinin kuzey-batısına inşa edilmiştir.

\subsection{Edremit Atıksu Arıtma Tesisi}

Edremit ileri biyolojik AAT'nin yapımı 2011-2013 yılları arasında tamamlanmıştır. Edremit ileri biyolojik AAT kapasite olarak 100.000 kişilik eşdeğer nüfus ve maksimum $21.840 \mathrm{~m}^{3} /$ gün debi ile hizmet verecek şekilde tasarlanmıştır. Arıtma tesisinde biyolojik fosfor havuzları ve uzun havalandırmalı aktif çamur prosesi kullanılarak azot, fosfor ve karbon giderimi yapılmaktadır. Atıksu ızgaralardan sonra giriş pompa istasyonuna gönderilmekte ve dalgı̨c pompayla tesisin birinci arıtma 
kademesine iletilmektedir. Kum tutucular hidrolik olarak $918 \mathrm{~m}^{3} / \mathrm{saat}$ debiye göre projelendirilmiştir. Havalandırmalı kum ve yağ tutucudan çıkan atıksu, geri devirden çıkan aktif çamurla karıştırılarak anaerobik havuza girmektedir. Atıksu, biyolojik fosfor giderme havuzlarından havalandırma ünitelerine alınmaktadır. Havalandırma havuzlarından çıkan aktif çamur dağıtım yapısından sonra çökeltme havuzlarına gelmekte ve yerçekimi etkisiyle çöktürülerek arıtılmış sudan ayrılmaktadır. Son çökeltme havuzundan çıkan ve içeriği büyük oranda biyolojik olan arıtma çamurları katyonik polielektrolit kullanarak santrifüj dekantörler yardımı ile susuzlaştırma işleminden geçirilmektedir. Katı madde oranı \%25'e çıkarılan arıtma çamuru kekler halinde traktör ve römorklar yardımı ile arıtma tesisinden uzaklaştırılmaktadır. Tesiste günlük olarak 8 ton arıtma çamuru oluşmaktadır [22].

\subsection{Gevaş Atıksu Arıtma Tesisi}

Gevaş ilçesi Selimbey mahallesinde kurulu bulunan tesis 2013 yılında İller Bankası Genel Müdürlüğü tarafindan yaptırılmış ve 2015 yılında işletmeye alınmıştır. Proje kapsamında deşarj yeri Van Gölü olarak belirlenmiştir. Proses seçiminde yürürlükte bulunan yönetmelik ve mevzuat gereğince 22.000 eşdeğer nüfusa hizmet vermek üzere inşa edilen Gevaş AAT uzun havalandırmalı aktif çamur prosesine sahip $7.607 \mathrm{~m}^{3} /$ gün kapasitelidir. Kaba atıklardan temizlenen atıksu kum, çakıl ve yağ gibi maddelerin atıksudan uzaklaştırılması amacı ile kum ve yağ tutucu ünitesine geçmektedir. Trapez yapılı kum tutucu, mekanik temizlemeli olarak tasarlanmıştır. Kum tutucular hidrolik olarak $316 \mathrm{~m}^{3} / \mathrm{saat}$ debiye göre projelendirilmiştir. Geri devirden gelen aktif çamur ve kum-yağ tutucu ünitesinden çıkan atıksu anaerobik havuzun toplama haznesinde karışarak havuzlara geçmektedir. Havalandırma havuzlarının şekli “Carousel Hendeği” şeklinde seçilmiştir. Böylece havuz içerisinde bulunan difüzörler ve mikserler yardımıyla havuzda oksik ve anoksik bölümler oluşturularak atıksu içerisinde bulunan organik maddelerin giderim prosesi gerçekleştirilmektedir. Çökeltme havuzunda döner köprüye bağlı üst sıyırıcı havuz yüzeyinde yüzen maddeleri ayırmaktadır. Çamur susuzlaştırma ekipmanı olarak dekantörler kullanılmaktadır. Çökeltme havuzlarında, aktif çamur yerçekim etkisi ile çöktürüldükten sonra çamurdan ayrılan su savaklanmaktadır. Son çökeltmeden gelen arıtma çamuru katyonik polielektrolit kullanarak dekantörler yardımı ile susuzlaştırılmaktadır. Tesiste günlük olarak 4 ton arıtma çamuru oluşmaktadır [23].

\subsection{Başkale Atıksu Arıtma Tesisi}

Başkale ilçesi Tepebaşı Mahallesi bölgesinde kurulu bulunan Başkale AAT 2029 ve 2049 yılları olmak üzere yaklaşık 21.000 eşdeğer nüfusa hizmet vermek üzere 2 kademede inşa edilmiştir. Başkale AAT'de kum tutucu sonrasında biyolojik fosfor gideriminin yapıldığ 1 anaerobik havuzlar bulunmaktadır. Anaerobik ortam şartlarında sadece organizmaların atıksu ile homojen olarak karışmasının sağlanması ve tabanda çökelmenin önlenmesi için karıştırma yapılmaktadır. Tesiste tıkanma problemlerini engellemek için tesise gelen atıksu kaba ve ince 1zgaralardan geçirilmektedir. Trapez yapılı kum tutucu, mekanik temizlemeli olarak tasarlanmıştır. Kum tutucular hidrolik olarak $185,1 \mathrm{~m}^{3} / \mathrm{saat}$ debiye göre projelendirilmiştir. Atıksu kum tutuculardan sonra giriş pompa istasyonuna gönderilmekte ve dalgıç pompayla tesisin biyolojik arıtma kademesine iletilmektedir. Oksidasyon havuzları şeklinde projelendirilen havalandırma havuzlarında nitrifikasyon-denitrifikasyon reaksiyonları ile azotlu bileşiklerin nitrit ve nitrata son olarak da azot gazına $\left(\mathrm{N}_{2}\right)$ dönüştürülmesi sağlanarak azot giderimi gerçekleştirilmektedir. Çökeltme havuzlarında, aktif çamur yer çekimi etkisi ile çöktürüldükten sonra çamurdan ayrılan su savaklanmaktadır. Çökeltme havuzlarının tabanından toplanan çamur, geri devir pompa odasına gönderilmektedir. Çamur susuzlaştırma ekipmanı olarak beltfiltre kullanılmaktadır. Beltfiltre \%0,8-1 kuru madde içeren çamurun içeriğini \%18 kuru maddeye çıkaracak özelliktedir [24].

\section{5. Çelebibağı Atıksu Arıtma Tesisi}

40.000 kişilik eşdeğer nüfusa hizmet vermek üzere 2014 tarihinde Van ili Erciş İlçesi 2,14 hektar alan üzerinde kurulan Çelebibağı İleri Biyolojik AAT 2023, Van gölü Tabiat Varlıkları Koruma Genel Müdürlüğü tarafından hassas alan olarak belirlenmiştir. Çelebibağı İleri Biyolojik AAT 2023 ve 2043 yılları olmak üzere iki kademede tasarlanmıştır ve uzun havalandırmalı aktif çamur prosesine sahip maksimum 4361,52 m³/gün kapasitelidir. Izgaralar zaman ve seviye ayarlı olarak çalışmaktadır. Atıksu 
içinde bulunan kum, çakıl gibi inert maddelerin sonraki ünitelere ve mekanik aksama zarar vermesini önlemek için tesiste 2 adet parabolik kesitli yatay akışlı havalandırmalı kum tutucu projelendirilmiştir. Kaba ve ince 1zgaralardan geçirilen atıksu ilk olarak havalandırmalı kum ve yağ tutucuya gelmektedir. Havalandırmalı kum ve yağ tutucudan çıkan atıksu, geri devirden çıkan aktif çamurla karışarak anaerobik havuza girmektedir. Atıksu, biyolojik fosfor giderme havuzlarından havalandırma ünitelerine alınmaktadır. Azot giderimi, organik azotun nitrit ve nitrata ve son olarak da azot gazına dönüştürülmesini sağlayan nitrifikasyon ve denitrifikasyon reaksiyonlarıyla gerçekleştirilmektedir. Çökeltme havuzlarında, aktif çamur yer çekimi etkisi ile çöktürüldükten sonra çamurdan ayrılan su savaklanmaktadır. Çökeltme havuzlarının tabanından toplanan çamur, geri devir pompa odasına gönderilmektedir. Son çökeltme havuzundaki arıtma çamuru kimyasal şartlandırıcı kullanılarak beltfiltre yardımı ile susuzlaştırma işleminden geçirilmektedir. Böylece katı madde oranı \%18'e çıkarılan arıtma çamuru, çamur kekleri halinde traktör ve römorklar yardımı ile arıtma tesisinden uzaklaştırılmaktadır. Susuzlaştırılan çamur, beltfiltrelerin altında bulunan burgu konveyör vasıtasıyla bina dışında bulunan kamyonlara yüklenerek tesisten uzaklaştırılmaktadır. Belt filtrelerden çıkan süzüntü suyu ise tesisin başına iletilmektedir. Tesisten günlük olarak 4 ton arıtma çamuru çıkmaktadır [25].

\subsection{Gölağzı Atıksu Arıtma Tesisi}

Erciş ilçesi Gölağzı mahallesinde kurulu bulunan yaklaşık 205.000 eşdeğer nüfusa hizmet vermek üzere inşa edilen maksimum $72.372 \mathrm{~m}^{3} /$ gün kapasiteli Gölağzı AAT iki kademeli olarak tasarlanmıştır. Bu proses birbirini sırayla takip eden birer anaerobik, anoksik ve oksik bölümden sonra çökeltme havuzundan ve anaerobik havuz girişinde bulunan çamur geri dönüş bağlantısından oluşmaktadır. Tesis ünitelerini tıkanma problemlerinden korumak amaciyla tesise iletilen atıksu kaba ve ince 1zgaralardan geçirilmektedir. Atıksu içinde bulunan kum, çakıl gibi inert maddelerin sonraki ünitelere ve mekanik aksama zarar vermesini önlemek için tesiste 2 adet parabolik kesitli yatay akışlı havalandırmalı kum tutucu bulunmaktadır. Arıtma tesisi ünitelerinde istenmeyen kirletici parametrelerin mekanik aksamlarının aşınmalarını önlemek amacıyla atıksuyun içindeki kum ve benzeri parametreler giderilmektedir. Havalandırmalı kum ve yağ tutucudan çıkan atıksu, geri devirden çıkan aktif çamurla birlikte anaerobik havuza girmektedir. Havalandırma havuzları için Carrousel tipi havuzlar seçilmiştir. Atıksudaki fosforun giderilmesi için havalandırma havuzu girişinde anaerobik bir tank tasarlanmıştır. Havalandırma havuzlarında hava ihtiyacı ince kabarcıklı difüzörler ile karşılanmaktadır. Difüzörlere hava blower tarafından temin edilmektedir. Blower havalandırma bölgesindeki çözünmüş oksijen konsantrasyonunu $2 \mathrm{mg} / \mathrm{L}$ değerinde tutacak şekilde değişken devirli çalışmaktadır. Çökeltme havuzlarında, aktif çamur yer çekimi etkisi ile çöktürüldükten sonra çamurdan ayrılan su savaklanmaktadır. Çöktürme havuzlarının tabanından toplanan çamur, geri devir pompa odasına gönderilmektedir. Çamur susuzlaştırma işleminde şartlandırıcı olarak katyonik polielektrolit kullanılmaktadır. Polielektrolit çözeltisi bir adet paket sistemde hazırlanmakta ve dozlama sistemi ile dekantörlere iletilmektedir. Çamur \%20-25 katı madde içeriğine getirildikten sonra kek halinde römorklar yardımıyla tesisten uzaklaştırılmaktadır [26].

Van Büyükşehir Belediyesi VASKİ Genel Müdürlügüü bünyesinde işletmeye alınmış olan atıksu arıtma tesislerinin işletmesi sırasında meydana gelen işletme problemleri tespit edilmesi ön görülmüş̧ür. Bu tespitleri belirlerken izlenecek yöntem; arıtma tesislerinin bulunduğu yöreye, iklime, nüfusa, tesis için yer seçimine bağlı olarak atıksu arıtma tesislerinin planlanması aşamasındaki proseslerin uygunluğunun araştırılmasını içermektedir. Atıksu arıtma tesisleri 2 kademeli olarak 15-35 yıl arası hizmet verecek şekilde planlanarak tasarlanmıştır. Tesislerde zamanla bölgenin durumu veya hızlı nüfus artışlarından dolayı debi artışları ve atıksu karakterinde bazı değişimler gibi sorunlar meydana gelmiştir. $\mathrm{Bu}$ sıkıntıların tesisleri nasıl etkilediği ve hangi önlemler alınması gerektiği araştırılmıştır. Ayrıca atıksu arıtma tesislerinin yapılması ve işletmeye alınması ile şimdiye kadar geçen zaman dilimi içerisinde meydana gelen yapım ve işletme problemlerine değinilmiştir. Çalışma sonunda bulunan ve tespit edilen işletme problemlerinin nedenleri ve çözüm önerileri irdelenerek değerlendirilmiştir 


\section{Van İli Atıksu Arıtma Tesisleri İşletme Sorunları ve Çözüm Önerileri}

Bu çalışma kapsamında Van iline hizmet veren İskele, Edremit, Gevaş, Başkale, Çelebibağ ve Gölağzı Atıksu Arıtma Tesisleri için proje ve işletmeden kaynaklanan sorunlar tesis özelinde tespit edilip, bu sorunların olumsuz etkileri belirlenmeye çalışılmıştır. Dolayısıyla tespit edilen gözlemlerle her tesisteki ünitelere ve tesisin geneline ait belirlenen sorunlar ve bunların çözümüne yönelik iyileştirme önerileri detaylı olarak sunulmuştur. Şekil 2'de arıtma tesislerine ait görüntülere yer verilmiştir. Şekil 3'de ise arıtma tesislerinde karşılaşılan bazı problemlerle ilgili görüntüler sunulmuştur.

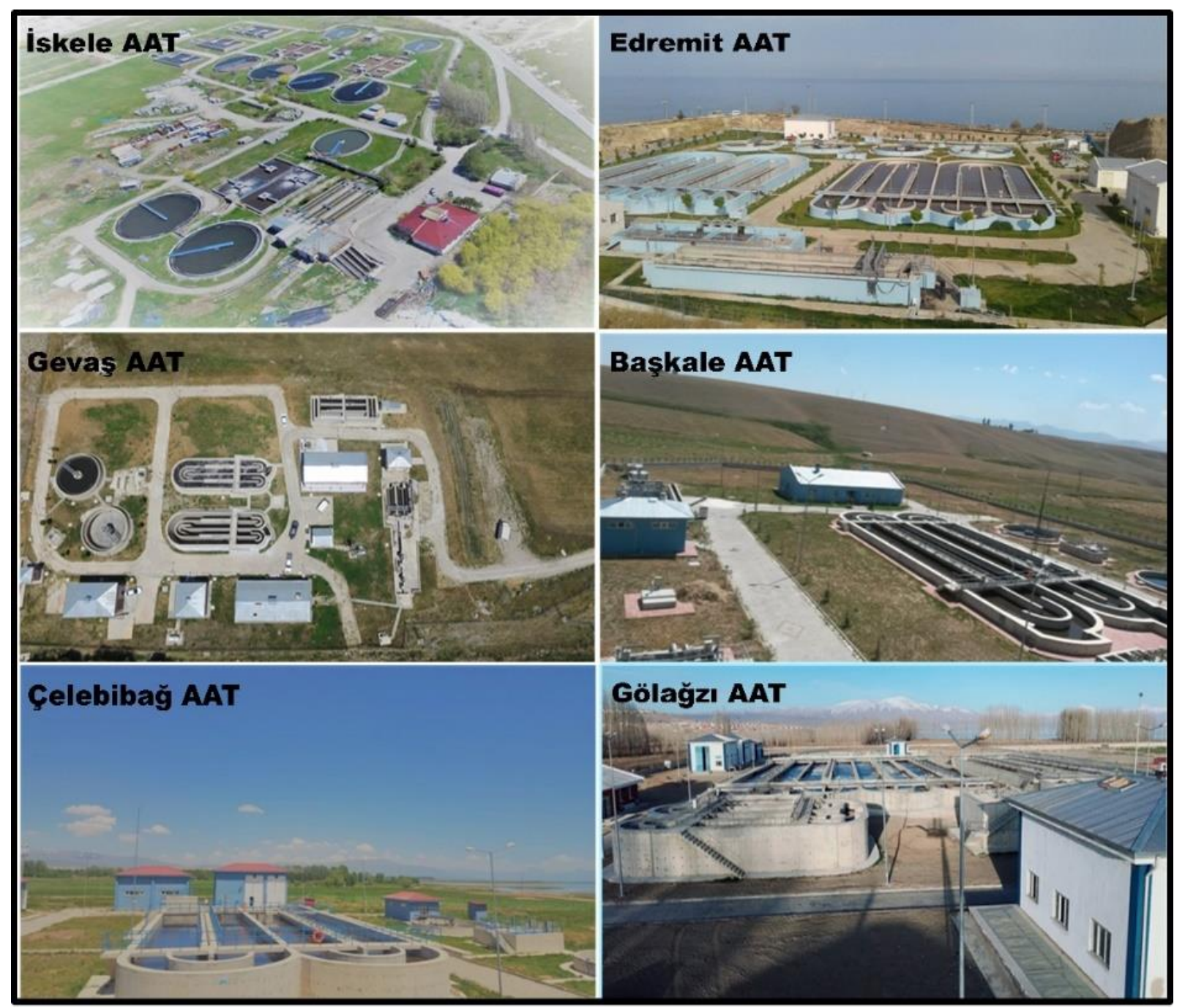

Şekil 2. Van İli evsel atıksu arıtma tesislerine ait görüntüler [27] 


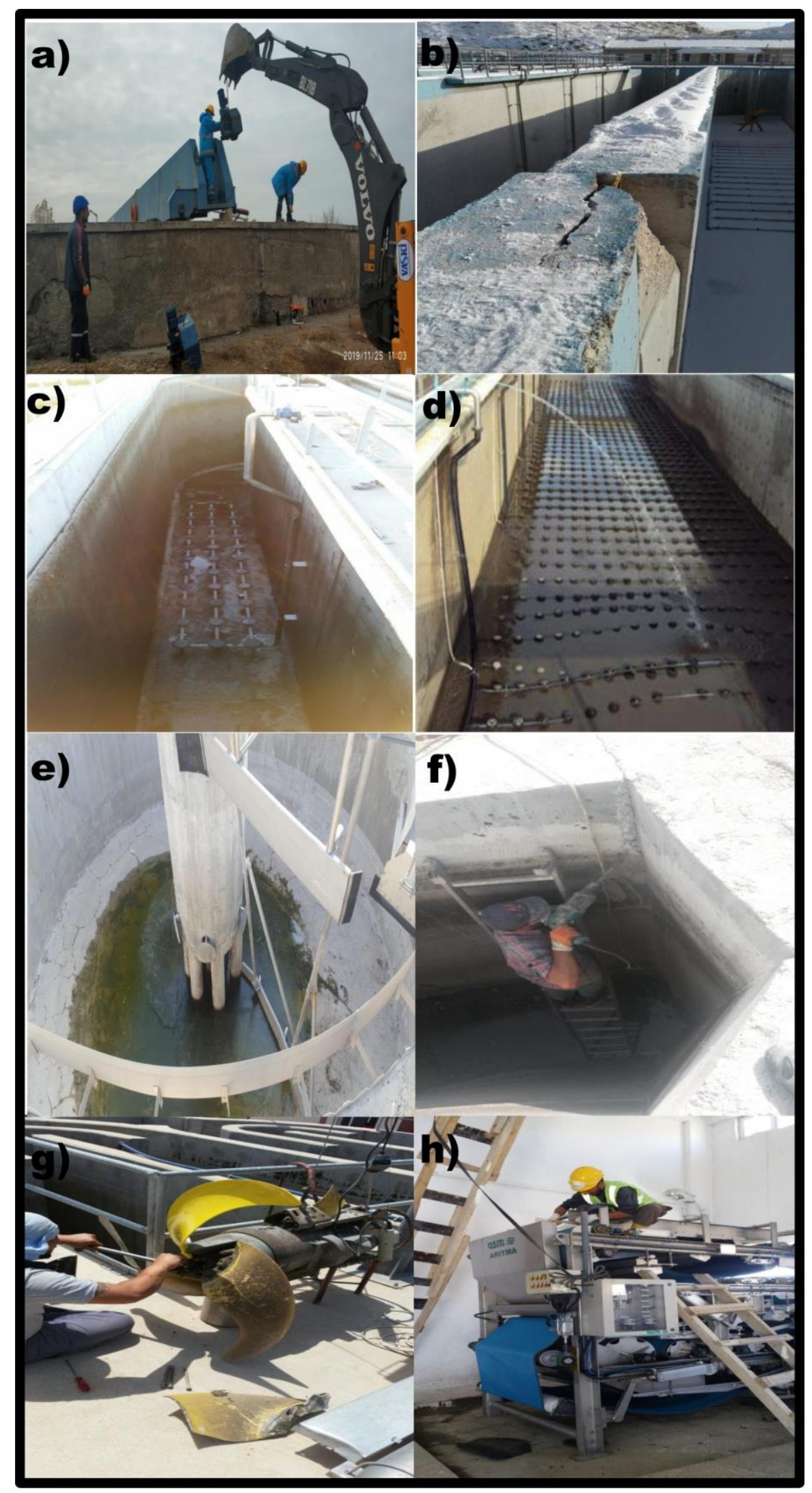

Şekil 3. Van ili evsel atıksu arıtma tesislerinde karşılaşılan sorunlarla ilgili görüntüler a) ve b) beton yapılardaki çatlaklarla ilgili problemler

c) ve d) difüzörlerle ilgili problemler

e) ve f) mekanik aksamlarla ilgili problemler

g) ve h) çamur uzaklaştırma sistemleriyle ilgili problemler [27] 


\section{1. İskele Atıksu Arıtma Tesisi}

İskele AAT; 320.000 eşdeğer nüfusa göre tasarlanmış olup 2015 yılına kadar yeterli olacağ1 düşünülmüştür. Ancak şu anda tesise bağlı olan nüfus TÜİK-2018 verilerine göre 597.964 kişidir [28]. Dolayısı ile tesis tam kapasite çalışmasına rağmen gelen atıksu arıtılamamakta, bu nedenle atıksuyun \%70'i by-pass edilmektedir. Bu durum yeni bir arıtma tesisi ihtiyacını doğurmaktadır. Bu kapsamda İskele AAT için sorunlar ve çözüm önerileri aşağıda detaylı bir şekilde incelenmiştir.

$\checkmark$ Sorun 1: İskele AAT'nin proje ömrünü tamamlamış olmasi; çözüm önerisi ise yeni bir tesisin inşa edilmesi.

$\checkmark$ Sorun 2: Giriş terfi ünitesinde kullanılan burgulu (arimed vidas1) pompaların tonlarca ağırlıkta ve çok büyük olmaları nedeniyle atıksuyu sağa sola sıçratması; çözüm önerisi ise mekanik ve elektrik aksamların yeni teknoloji ile değiştirilmesinin hem çok maliyetli olması hem de betonarme ömrünü tamamlamış yapının bu aksamları taşıyamayacağından dolayı daha ekonomik olması bakımından yeni bir tesisin inşa edilmesi.

$\checkmark$ Sorun 3: Mevcut tesisin proje sahası incelendiğinde kanalların çökmüş ve havuzların beton duvarlarının ise kullanılamaz durumda olması; çözüm önerisi ise bakım-onarım çalışmasından ziyade betonarme yapiların yeniden yapılması.

$\checkmark$ Sorun 4: Yağmurlu havalarda tesise aşırı miktarda kum-çakıl malzemenin gelmesi; çözüm önerisi ise tesiste kum tutucu mevcut olmasına rağmen ilave olarak tesis girişinde ana kolektör üzerine uygun ebatlarda iki bölmeden oluşan ön kum tutucu havuzların yapılması, mevcut kum tutucuların periyodik olarak temizlenmesi aksi takdirde kum ve çakılın tesisin her kademesine taşınarak tesisin verimini düşürmektedir.

$\checkmark$ Sorun 5: Yerleşim alanına $50 \mathrm{~m}$ mesafede hakim rüzgar yönünde kurulmuş olan AAT'de ön arıtma üniteleri ( kaba 1zgara, ince 1zgara, kum tutucular), tesiste kapasite yetersizliğinden dolay1 fazla bekletilen kaba malzeme (kâğıt, poşet, tahta vs.), çamur susuzlaştırma ünitesi olarak kullanılan belt preslerde ve çamur lagünlerinde özellikle yaz aylarında koku ve sinek probleminin yaşanması ve bu durumun çevre halkını rahatsız etmesi; çözüm önerisi ise AAT'de özellikle koku çıan ünitelere koku giderme proseslerinin entegre edilmesi.

$\checkmark$ Sorun 6: Havalandırma havuzlarında kullanılan yüzey aeratörlerinin yetersiz ve ölü nokta havalandırma yapması ve aynı zamanda yine boyut olarak büyük ve ağır olmalarının bakım ve onarım çalışmalarını zorlaştırması; çözüm önerisi ise mekanik ve elektrik aksamların yeni teknoloji ile değiştirilmesinin hem çok maliyetli olması hem de betonarme ömrünü tamamlamış yapının bu aksamları taşıyamayacağından ötürü daha ekonomik olması bakımından yeni bir tesisin inşa edilmesi.

$\checkmark$ Sorun 7: Kentsel Atıksu Arıtımı Yönetmeliğinin hassas alan ilan edilen alıcı ortamlarda azot ve fosfor giderimininde yapılması gerekliliği belirtilmiş olmasına rağmen karbon giderimi yapan biyolojik prosese sahip İskele AAT çıkış suyu değerlerinin mevzuatta belirtilen sınır değerleri sağlıyor olsa da azot ve fosfor giderimi yapan özelliğe sahip olmaması; çözüm önerisi ise Van ilinin azot, fosfor ve karbon giderimi yapan yeni bir arıtma tesisine ihtiyaç duyması.

$\checkmark$ Sorun 8: Çamur susuzlaştırma ünitesi olarak kullanılan belt presinin hem düşük oranda çamur kuruluk oranına sebep olması hem de koku ve sineklenme problemine sebep olması gibi tesis içindeki mekanik ve elektrik aksamının eski teknoloji olması ve proje ömürlerini tamamlamış durumda olması; çözüm önerisi ise mekanik ve elektrik aksamların yeni teknoloji ile değiştirilmesinin hem çok maliyetli olması hem de betonarme ömrünü tamamlamıs yapının bu aksamları taşıyamayacağından ötürü daha ekonomik olması bakımından yeni bir tesisin inşa edilmesi.

$\checkmark$ Sorun 9: Beltpress filtre ile \%18 katı madde içerikli susuzlaştırılmış çamur elde edilen İskele AAT'de çamurun nihai bir bertarafı için çamur lagünleri tasarlamıştır. Ancak yerleşim alanının içinde kalan tesiste koku ve sinek problemlerinden dolayı âtıl durumda olan çamur lagünlerinde çamur bertarafının yapılamaması; çözüm önerisi ise atık çamurların yerleşim yerine uzak bir mesafede bulunan bir alanda bertaraf edilmesi.

$\checkmark$ Sorun 10: Yerleşim yeri içinde kalan İskele AAT’nin tesis sahasına, etrafinda bulunan tel örgülerinin kesilerek kaçak geçişlerin olması ve kesilen tellerin onarılmasına rağmen izinsiz geçişlerin devam etmesi; çözüm önerisi ise hem tesisin ve hem de çevre halkının güvenliği için tesisin etrafına en az 2 m yüksekliğinde çevre duvarının örülmesi. 
Sorun 11: İskele AAT'nin çıkış suyunun deşarj öncesinde dezenfeksiyon işleminden geçirilmemesi; çözüm önerisi ise arıtma tesisi çıkış suyunun alıcı ortamı olarak rekreasyonel amaçlı kullanılan Van Gölü’ne deşarj edilmeden önce çevre sağlığı ve halk sağlığını korumak amacıyla dezenfeksiyon işleminden geçirilmesi [27].

\subsection{Edremit Atıksu Arıtma Tesisi}

Edremit AAT; $21.840 \mathrm{~m}^{3} /$ gün kapasiteli olup, başlangıçta 40.000 kişilik eşdeğer nüfus verisi dikkate alınarak tasarlanmış ve belirlenen kapasitenin yetmeyeceği düşünülerek uygulama aşamasında 100.000 kişilik eşdeğer nüfus verisi baz alınıp proje revize edilerek yeniden tasarlanmıştır. Ancak, yapılan teknik inceleme neticesinde revize edilen projede imalat eksiklikleri ve bazı uygulama hataları tespit edilmiş ve sorunlar ilgili birimin teknik çalışması sonucu giderilmeye çalışılmıştır. Bunun yanında Edremit AAT için diğer sorunlar ve çözüm önerileri aşağıda detaylı bir şekilde incelenmiştir [27, 29].

$\checkmark$ Sorun 1: Edremit AAT’nin, ilgili mevzuat hükümlerini yerine getirecek şekilde dizayn edilmiş olmasına rağmen, projede tasarım hatası olarak kademelendirme yıl bazında yapılmamış ve gelecekteki nüfus için projeksiyon hesabı veya proje ömrüne bağlı olarak kapasite artışı için ek alan tahsisinin planlanmamış olması; çözüm önerisi ise tesis sahası yakınındaki arazilerde fizibilite çalışması sonrasında gelecek nüfus oranı dikkate alınarak ek alan tahsis çalışmalarının başlatılması.

$\checkmark$ Sorun 2: Arıtma tesisinin yer seçimi olarak yüksek kotta ve hâkim rüzgâr yönünde kurulmuş olması nedeniyle özellikle havaların sıcak ve rüzgârlı olduğu dönemlerde kötü kokunun çevre halkını rahatsız etmesi; çözüm önerisi ise yüksek maliyetle kurulan tesisin taşınması veya başka yeni bir tesisin inşasının maliyet açısından mümkün olmaması nedeniyle arıtma tesisine koku giderme ünitelerinin kurularak çıkan kokuların minimize edilmesi.

$\checkmark$ Sorun 3: Tesisteki çoğu üniteye ait betonarme duvarlarda, segregasyonlar, soğuk dezler ve sızma oluşan bölgelerde çalı̧̧malar yapılması; çözüm önerisi ise gelecekte eklenecek hidrolik yüklemenin kontrol edilerek bir takım izolasyon çalışmalarının yapılması, ayrıca bu yönde sızma yapan tayrot deliklerinin uygun malzeme ile kapatılması, uygun bir yalıtım malzemesi ile kaplanması, segregasyonlar ve soğuk derzlerin onarılması.

$\checkmark$ Sorun 4: İmalat eksiklileri olarak projede olmasına rağmen uygulama sahasında olmayan çalışma sırasında tespit edilen eksiklerin giderilmesi; çözüm önerisi ise 1 adet giriş terfi pompası, 1 adet hava üfleyici ve 1 adet çözünmüş oksijen setinin yerine montajlanarak eksikler giderilmiştir.

$\checkmark$ Sorun 5: Tesisin havalandırmalı kum ve yağ tutucu ünitesindeki hatalı ve işlevsiz yağ alma yapısı nedeniyle kanalda birikmiş olan yağların giderilmesini sağlayabilmek için betonarme duvar üzerinde açılan deliklerden yağların yere dökülmesi ve tesiste istenmeyen kokulara sebebiyet vermesi; çözüm önerisi ise kanalda biriken yağlar için bantlı ve helezon konveyör veya borulama yapısı gibi kapalı bir sistem kurularak uygun yağ alma prosesinin teşkil edilmesi.

$\checkmark$ Sorun 6: Uygulama hatası olarak; çalışma sırasında tespit edilen tesisin havalandırma havuzlarında 9" (dokuz inç) disk tipi difüzörlerin anoksik ve oksik zonları oluşturacak şekilde yerleştirilmemesi; çözüm önerisi ise havalandırma havuzunda yanlış yerleştirilen difüzörler sökülerek anoksik ve oksik bölgeler oluşturularak sorun giderilmiştir.

$\checkmark$ Sorun 7: Uygulama hatası olarak; çalışma sırasında tespit edilen son çökeltme havuzlarında kullanılan V savaklarının aynı kotta olmaması sebebi ile çıkış suyunun eşit savaklanamadı̆̆ının tespit edilmesi; çözüm önerisi ise savakların aynı kota getirilerek çıkış suyunun eşit savaklanması sağlanarak sorun giderilmiştir.

$\checkmark$ Sorun 8: Uygulama hatası olarak; çalışma sırasında tespit edilen son çökeltme havuzunda döner köprü yolunun aşırı pürüzlü olması ve aynı eksende olmaması, döner köprü tekerini sürekli bir şekilde deforme etmesi ve dinamoyu zorlayarak kullanım verimini düşürmesi ve döner köprünün aşırı vibrasyonla hareket etmesi sonucu çamurun çökelebilirliğini engellemesi; çözüm önerisi ise son çökeltme ünitesinde döner köprünün tek kotta ve pürüzsüz olması için minimum $3 \mathrm{~cm}$ 'lik mozaik malzemeden kaplama yapılması.

$\checkmark$ Sorun 9: Çökeltme ünitesinde havuzdaki oturmadan kaynaklı dengeli bir savaklama işlemi yapılamaması; çözüm önerisi ise, savaklarda onarım yapılarak sorunun giderilmesi.

$\checkmark$ Sorun 10: Dekantör ve çamur yoğunlaştırma ünitelerinden ayrılan çözünmüş polielektrolit içeren faz suyunun cazibesiyle tesiste kaba ızgaranın öncesine devredilmesi ve polielektrolitin yapışkan 
özelliği dolayısıyla boru ve pompa gibi aksamlarda tıkanmalara yol açması, ayrıca özellikle de yağmurlu günlerde tesise gelen atıksu debisinin fazla olmasından kaynaklı geri tepmeler ve giriş bacasında taşmalar görülmesi; çözüm önerisi ise çamurdan ayrılan faz suyunun projeye uygun olarak anaerobik ünitenin başına geri devrettirilmesi [29].

$\checkmark$ Sorun 11: Arıtma tesisine ait projede üretilen çamur için \%25 kuru madde oranına getirildikten sonra yapılması gereken herhangi bir çözüm önerisi mevcut değildir. Atık çamur için her ne kadar yeni bir alan arayışı söz konusu olsa da tesisin yakınında bulunan bir alana gelişi güzel bir şekilde depolanmaktadır. Yapılan bu işlem sonucu meydana gelen kötü kokuların çevre halkını rahatsız etmesi; çözüm önerisi olarak sunulacak farklı alternatifler söz konusudur. Bunlardan biri açık ya da kapalı tip olacak şekilde solar ısıtmalı çamur kurutma yatağının kurulması ve çamur kuru madde oranının \%50'ye getirilip, katı atık depolama tesisine gönderilmesidir. İkinci alternatif çamur kuru madde oranın $1 \% 90$ düzeyine getirecek endüstriyel tip çamur kurutma sistemi ile kuru maddenin çimento fabrikası gibi bazı fabrikalarda yakıt olarak değerlendirilmesi ki tesisin hemen yakınında Çimento Fabrikası mevcuttur. Ayrıca kuru maddenin gübre olarak da kullanılması düşünülebilir. Üçüncü alternatif ise çamur kurutma merkezi kurularak tesislerde oluşan çamurların bu merkeze nakledilmesi ve kurutulduktan sonra yakıt veya gübre amaçlı kullanılmasıdır. Son alternatif çözüm önerisi ise mevzuatta istenen uygun kuru madde oranı sağlanan çamurun doğrudan ya da pamuk sapı ve fistık kabuğu gibi benzeri maddeler ile karıştırıldıktan sonra tarımsal faaliyetlerde gübre amaçlı kullanılması.

$\checkmark$ Sorun 12: Edremit AAT çıkış suyuna herhangi bir dezenfeksiyon işleminin uygulanmaması; çözüm önerisi ise arıtma tesisi çıkış suyunun alıcı ortamı olarak Van Gölü’nün rekreasyon ve yüzme amaçlı kullanımından dolayı çevre sağlığı ve en önemlisi de halk sağlığını korumak amacıyla tesis çıkış suyunun göle deşarjından önce dezenfeksiyon işlemine tabi tutulması.

\subsection{Gevaş Atıksu Arıtma Tesisi}

Gevaş AAT 22.000 eşdeğer nüfusa hizmet vermek üzere inşa edilmiş olup, $7.607 \mathrm{~m}^{3} /$ gün kapasitelidir. Tesise ait sorunlar ve çözüm önerileri aşağıda detaylı bir şekilde incelenmiştir.

$\checkmark$ Sorun 1: Gevaş Atıksu Arıtma Tesisinin uzun havalandırmalı aktif çamur ünitesinde, havuzun tabanına yerleştirilen disk tipi difüzörler havuz tabanınına homojen olarak yerleştirilmediği için oksik ve anoksik bölgeler uygun bir şekilde oluşamadığından dolayı aktif çamur işletme sorunları ile karşılaşılması; çözüm önerisi ise havalandırma ünitesinde difizörlerin havuz tabanına homojen olacak şekilde döşenmesi.

$\checkmark$ Sorun 2: Havalandırma ünitesinde işletme parametrelerinin en önemlilerinden biri olan çözünmüş oksijen konsantrasyonunu ölçen oksijenmetrenin havuz içinde özellikle çıkış bölmesine montajının yapılmaması; çözüm önerisi ise havalandırma ünitesinde özellikle de anaerobik koşulların oluşmaması ve yüksek kaliteli bir çıkış suyu elde edebilmek için havuz genelinde çözünmüş oksijen konsantrasyonunun ortalama 2 ila $4 \mathrm{mg} / \mathrm{L}$ arasında olacak şekilde takibinin yapılması [25-26]. Bu kapsamda havuz içinde oksijenmetrelerin uygun yer ve eksene montajının yapılması ile sorun önemli bir şekilde giderilmiştir.

$\checkmark$ Sorun 3: Havalandırma işleminin özellikle havuzun çıkış bölmesinde istenenden fazla olduğundan hidrolik türbülansın meydana gelerek biyolojik yumakların parçalanmasına ve çıkış suyunda flokların oluşması ile bakteri kaçaklarına neden olması. Ayrıca bu durumun son çökeltme ünitesinde, çamur kabarmasına, iğne uçlu flokların oluşmasına ve çıkış suyunun bulanık ve kötü kokulu olmasına neden olması [27]; çözüm önerisi olarak havuzun çıkış bölmesi boyunca döşenen difüzörlerin bir kısmının difüzör montajı yapılmayan bölmeye aktarılarak yerleştirilmesi ile ilgili çalışmalar yapılmıştır. Beşkat, [15], tarafından Siverek Atıksu Arıtma Tesisi özelinde işletme problemlerinin tespitine yönelik yapılan çalışmada havalandırma havuzunda meydana gelen türbülansın tıkalı difüzörlerden ve buna bağlı olarak havuz için homojen bir dağılım olmamasından kaynaklandığı tespit edilmiştir. Çözüm önerisi olarak da difüzörlerin temizlenmesi veya değiştirilmesi neticesinde havuz içinde homojen bir oksijen dağılımının sağlanacağı ifade edilmiştir. Gevaş AAT için de bu durumun benzer şekilde farklı ve fazla havalandırma neticesinde meydana geldiği ifade edilebilir. Benzer sorunlar ve çözümlere Yıldız ve Çekim, [30], tarafından yapılan çalışmada da değinilmiştir. 
Sorun 4: Biyolojik fosfor giderme ve uzun havalandırmalı aktif çamur ünitelerinde homojen karışım sağlamak, çökelmeyi engellemek ve iç resirkülasyon amacı ile kullanılan dalgıç mikserlerin yer ve yön aktarımı için doğru seçim yapılmaması; çözüm önerisi ise mevcut dalgıç mikserlerin, yer ve yön seçimi doğru olacak şekilde amacına uygun yerlere montaj1 ile ilgili çalışma yapılmış ve sorun giderilmiştir [27-29].

$\checkmark$ Sorun 5: Çamur susuzlaştırmada mevcutta bir adet dekantörün kullanılması ve olası teknik bir arıza neticesinde çamur çekme işleminin tehlikeye düşmesi; çözüm önerisi ise ciddi işletme sorunu ile karşılaşılmaması için dekantörün 1 asıl ile birlikte 1 yedeğinin tedarik edilmesi.

$\checkmark$ Sorun 6: Tesiste \%25 katı madde içerikli susuzlaştırılmış çamur için nihai bir bertaraf tesisi tasarlanmamış olması; çözüm önerisi ise bu konuyla ilgili çamur yönetim planının hızlı bir şekilde hazırlanmasi.

\subsection{Başkale Atıksu Arıtma Tesisi}

Yaklaşık 21.000 eşdeğer nüfusa hizmet vermek üzere inşa edilen Başkale AAT kum tutucular sonrasında biyolojik fosfor giderimi yapan anaerobik havuzlar şeklinde tasarlanmıştır. Tesise ait sorunlar ve çözüm önerileri aşağıda detaylı bir şekilde incelenmiştir.

$\checkmark$ Sorun 1: Başkale AAT'nin mevcut durumda projelendirme yapılırken tasarım debilerinin ve diğer tüm hesaplamalarının doğru yapılmasına rağmen kişi başı su tüketim miktarı düşük alındığı için kapasitesinin yetersiz kalması. Bu nedenle tesise beklenenden daha fazla atıksu geldiği için atıksuyun \%20'sinin arıtılamaması; çözüm önerisi ise ön arıtma ünite sayılarının arttırılması ve ikinci kademe biyolojik arıtma ünitelerinin kademe yılını beklemeden inşa edilmesi.

$\checkmark$ Sorun 2: Kum tutucu ve son çökeltme havuzlarının köprü yollarında kış mevsiminde yaşanan donma nedeniyle köprünün görevini yerine getirememesi nedeniyle önlem amaçlı tuzlama işleminin yapılması ve bundan kaynaklı beton kısımların zamanla zarar görmesi; çözüm önerisi ise döner köprü tekerlerinin önüne kar paletlerinin eklenmesi ve uygun yöntemler kullanılarak 1sitma sistemlerinin kurulmas1 [27].

$\checkmark$ Sorun 3: Tesiste çamur susuzlaştırma ünitesinde çamur hatları ile polielektrolit dozlama hatlarının kış mevsiminde yaşanan soğuk hava koşulları nedeniyle donması ve buna bağlı olarak kış aylarında çamur çekiminin yapılamayarak arıtma verimini aşırı düşürmesi ve aktif çamur işletme problemleri ile karşılaşılması; çözüm önerisi olarak çamur susuzlaştırma binasına isıtma sisteminin kurulması, bina içi ve dışındaki boru hatlarının uygun izolasyon malzemesi ile kaplanması ve böylece 1sı kaybının önlenmesi.

$\checkmark$ Sorun 4: Başkale AAT'de çamur susuzlaştırma prosesi olarak kullanılan beltfiltrenin teknolojisinin eski olması ve yavaş çalışması gibi nedenlerle daha fazla miktarlarda polielektrolit kullanımı, beltfiltrelerin geri yıkanması esnasında aşırı zaman ve su kaybının meydana gelmesi ve teknik bir arıza çıkması durumunda arızanın tespiti ve onarımının oldukça zor ve uzun zaman alması gibi işletme zorluklarına sebep olması; çözüm önerisi ise beltfiltre yerine işletme maliyeti, kolaylığı ve verim açısından daha elverişli bir sistem olarak mekanik çamur susuzlaştırma ünitelerinden biri olan dekantörlerin kullanılması. Dekantörler yüksek yoğunluklu atık çamur oluşturan en verimli proseslerden biridir. En büyük avantajı ise ünite içine sürekli bir çamur girişi sayesinde tam ve sürekli bir işletme sağlanmasıdır. Ayrıca kapalı tasarımları sayesinde koku problemini de engellemeleri başka bir avantajı olarak ifade edilebilir.

$\checkmark$ Sorun 5: Tesiste beltpress filtre ile \%18 katı madde içerikli susuzlaştırılmış çamur için nihai bir bertaraf tesisinin tasarlanmamış olması; çözüm önerisi ise çamur yönetim planının hızlı bir şekilde hazırlanması.

$\checkmark$ Sorun 6: Atıksu arıtma tesisine ait projelendirmede açığa çıkan çamurun \%18 kuru madde oranına getirildikten sonra bertarafına dair öneri niteliğinde bir bilgi mevcut olmaması; çözüm önerisi olarak ilk alternatif; kurulacak olan açık ya da kapalı tip solar 1sıtmalı çamur kurutma yatağında $\% 50$ çamur kuru madde oranına ulaşıldıktan sonra katı atık depolama tesisine gönderilmesi. İkinci alternatif; çamur kuru madde oranını \%90'lara çıkaracak endüstriyel tip çamur kurutma sistemi kurulması ile elde edilen kuru maddenin tarımsal faaliyetlerde gübre olarak kullanımı ya da Çimento Fabrikası ve benzeri fabrikalara göndererek yakıt olarak kullanılması. Üçüncü alternatif; uygun bir alanda çamur kurutma merkezinin kurulması ve çamurların buraya nakledilip kurutulduktan sonra yakıt veya gübre olarak kullanılması. Son alternatif olarak ise mevzuat 
çerçevesinde çamurun istenen kuru madde oranına getirildikten sonra doğrudan veya pamuk sapı, fistık kabuğu ve benzeri maddelerle karıştırıldıktan sonra tarımsal faaliyetlerde gübre olarak kullanılması şeklinde sıralamak mümkündür [29].

$\checkmark$ Sorun 7: Tesise ait çıkış sularının dezenfeksiyon işlemine tabi tutulmadan Dicle Nehri'ni besleyen bir dereye deşarj edilmesi; çözüm önerisi ise alıcı ortamın aynı zamanda hassas alan niteliğinden dolayı atıksuların dezenfeksiyon işlemine tabi tutulduktan sonra deşarj edilmesi.

\section{5. Çelebibağı Atıksu Arıtma Tesisi}

Çelebibă̆ AAT 40.000 kişilik eşdeğer nüfusa hizmet vermek üzere maksimum 4361,52 $\mathrm{m}^{3} / \mathrm{gün}$ kapasiteli olacak şekilde tasarlanmıştır. Tesise ait sorunlar ve çözüm önerileri aşağıda detaylı bir şekilde incelenmiştir.

$\checkmark$ Sorun 1: Havalandırma ünitelerinde kullanılan disk tipi plastik malzemeden yapılmış delikli borulardan oluşan difüzörlerin monte edilmesi sırasında yapılan hatalar arasında havuz içinde atıksuya yön veren mikserlere difüzörlerin çok yakın yerleştirilmesi ve kalitesiz malzeme tercihi sonucunda sık sık arıza yapması, ayrıca hava borularındaki bağlantı noktalarından içeri doğru çamurun girmesiyle hava verme yeteneğini kaybeden difüzörlerin deforme olmasi; çözüm önerisi ise mikser ile difüzör hava hatları arasındaki mesafenin çok iyi ayarlanması, ayrıca su altında kalan hava iletim hatlarının paslanmaz çelik malzemeden tercih edilmesi.

$\checkmark$ Sorun 2: Çelebibağ AAT' de çamur susuzlaştırma prosesi olarak kullanılan beltfiltrenin eski olması ve yavaş çalışması gibi nedenlerden dolayı daha fazla miktarlarda polielektrolit kullanımı, beltfiltrelerin geri yıkanması esnasında aşırı zaman ve su kaybının meydana gelmesi ve teknik bir arıza çıkması durumunda arızanın tespiti ve onarımının oldukça zor ve uzun zaman alması gibi işletme zorluklarına sebep olması; aynı soruna ait çözüm önerisi olarak Başkale AAT için önerilen alternatiflerin sunulmasi.

$\checkmark$ Sorun 3: Çelebibağ Atıksu Arıtma Tesisine ait projelendirmede açığa çıkan çamurun \%18 kuru madde oranına getirildikten sonra bertarafına dair öneri niteliğinde herhangi bir bilginin mevcut olmaması; aynı soruna ait çözüm önerisi olarak Başkale AAT için önerilen alternatiflerin sunulmas1 [29].

\subsection{Gölağzı Atıksu Arıtma Tesisi}

Gölağzı AAT 205.000 eşdeğer nüfusa hizmet vermek üzere inşa edilmiş olup, maksimum $72.372 \mathrm{~m}$ /gün kapasiteli ve iki kademeli olarak tasarlanmıştır. Tesise ait sorunlar ve çözüm önerileri aşağıda detaylı bir şekilde incelenmiştir.

$\checkmark$ Sorun 1: Gölağzı AAT için fizibilite çalışmalarının iyi yapılmamış olmasının yanında tesise gelen atıksu içerisinde tesisteki ızgaraların, pompa ünitelerinin, kum ayırma ünitesi gibi ekipmanların tıkanmasına sebep olan büyük miktarlarda saman bulunması büyük sorun teşkil etmektedir; çözüm önerisi ise fizibilite çalışmalarının gerçeği yansıtacak şekilde ve doğru bir planlama ile gerçekleştirilerek ek filtreleme prosesleri sayesinde saman probleminin ortadan kaldırılması. Beşkat [15], tarafından yapılan çalışmada Siverek AAT'nin konumu itibariyle hayvancılıkla uğraşıldığ için benzer şekilde arıtma tesisine gelen atıksular içerisinde fazla miktarda saman olduğu ve bunun da tesis içerisinde bulunan ekipmanların tıkanmasına ve bozulmasına sebep olduğu ifade edilmiştir [27].

$\checkmark$ Sorun 2: Tesiste santrifüj dekantörlerle $\% 25$ katı madde içerikli susuzlaştırılmış çamur için nihai bir bertaraf tesisi tasarlanmamış olması; çözüm önerisi ise çamur yönetim planının hızlı bir şekilde hazırlanması.

\section{Sonuçlar ve Öneriler}

Van ilinde işletmede olan atıksu arıtma tesislerinde en çok karşılaşılan problemler; fizibilite, etüt ve proje çalışmalarındaki eksiklik ve hatalar, betonarme yapılarda sorunlar, iklim koşullarına uygun olmayan proses seçimi, yanlış veri kullanımı, kapasite yetersizliği gibi işletme problemlerinin çoğunun tip proje uygulamalarından ötürü yanlış projelendirmeden kaynaklandığı tespit edilmiştir.

Van ili atıksu arıtma tesislerinde karşılaşılan problemlerin sebebleri detaylandırıldığında; 
- Tesis tasarımında proses, ekipman ve enstrümantasyon açısından hatalı seçimlerin yapılması ve inşaat aşamasında yanlış uygulamaların yapılması.

- Mevcut atıksu arıtma tesislerinde, tesisi işletecek bilgiye sahip donanımlı personelin olmaması ve belediye imkanlarının yetersiz kalması.

- Van ilinde işletilen atıksu arıtma tesislerinden çıkan ve belediyeler açısından büyük bir problem olan arıtma çamurları hakkında genel bir çamur yönetim planı oluşturulmamış olması.

- Atıksu arıtma tesislerinin gerek yapımı, gerekse işletimi için yüksek maliyetler gerekmektedir. Belediyeler genelde bu maliyeti karşılamakta zorluk çektiklerinden dolayı bu tesislerin inşaatını Bakanlık, İller Bankası gibi başka kurumlara yaptırmaktadır. Bu kurumlar ise; işletme konusunda çok tecrübeli olmadıklarından ve yerel bölgeye fazla hakim olamadıklarından, bölgeye tam uyumlu olmayan ve işletme bakımından problem çıkartacak tip projeleri uygulamaya almaktadırlar.

Mevcut atıksu arıtma tesislerinin çıkış sularının alıcı ortama deşarj edilmeden önce dezenfeksiyon işlemine tabi tutulması gereklidir. Evsel atıksular biyolojik arıtma süreçlerinden sonra bile yüksek miktarda patojen mikroorganizma içermektedir. Bu nedenle, Van ilindeki arıtılmış atıksuların dezenfekte edildikten sonra alıcı ortama deşarj edilmesi önem arzetmektedir. Atıksu arıtma tesislerinde kaliteli bir çıkış suyu elde etmek için proses seçimi, planlama ve projelendirme süreçlerine büyük bir önem verilmeli ve bu süreçte yeterli sayıda çalışmalar gerçekleştirilmelidir. Düzenli bakım planları yapılmalı ve bunların tarihli olarak kayıtları alınmalıdır. Bakım planında görünen fakat bakımları yapılamamış olanlara öncelik verilmelidir. Bu problemlerle karşılaşmamak için gerek tesisleri dizayn edenlerin gerekse işletenlerin deneyimli kişi ya da kuruluşlarla birlikte çalışılması, ihtiyaç duyulan ekipmanların temin edilmesi ve geliştirilmesi gerekmektedir. Arıtma tesislerinde karşılaşılan bir çok problemin çözümü bu çalışma kapsaminda belirtilmiştir. Sorun yaşanan atıksu arıtma tesislerinde bahsedilen çözüm önerilerinin uygulanması durumunda tesislerin çoğunun istenilen verimde çalışması sağlanacaktır. Ancak, bu çözüm önerilerinin uygulanabilmesi için, yaşanan sorunlara çözümleri uygulayabilecek kapasitede kalifiye personelin bulundurulması veya mevcut personele özel bir eğitim verilmesi gerektiği düşünülmektedir.

\section{Yazarların Katkısı}

Yazarlar makaleye eşit oranda katkı sağlamışlardır.

\section{Çıkar Çatışması Beyanı}

Yazarlar arasında herhangi bir çıkar çatışması bulunmamaktadır.

\section{Araştırma ve Yayın Etiği Beyanı}

Yapılan çalışmada araştırma ve yayın etiğine uyulmuştur

\section{Kaynaklar}

[1] Yetis R., Atasoy A.D., Demir Yetis A., Yesilnacar M.I. 2018. Balıklıgöl havzası su kaynaklarının nitrat ve nitrit seviyelerinin belirlenmesi. Çukurova Üniveristesi Mühendislik Fakültesi Dergisi, 33 (1): 47-54.

[2] Yetiş R., Atasoy A.D., Demir Yetiş A., Yeşilnacar M.I. 2019. Hydrogeochemical characteristics and quality assessment of groundwater in Balikligol basin, Sanliurfa, Turkey. Environmental Earth Sciences, 78: 1-17.

[3] Demir Yetis A., Selek Z., Selek B. 2019. Ecosystem Based Water Quality Management. In: Wetlands and Their Interaction with Water Resources in Terms of Water Quality, 1st edn., Edited by Selek Z., Karaaslan Y., Republic of Turkey Ministry of Agriculture and Forestry, Ankara, 345-372.

[4] Selek Z., Demir Yetiş A. 2017. Assessment of nitrate contamination in a transnational groundwater basin: A case study in the Ceylanpinar plain, Turkey. Environmental Earth Sciences, 76 (20): 1-11. 
[5] Bayhan İ., Yeşilnacar M.I., Demir Yetis A., Tutkun E. 2020. An evaluation of drinking-usage water quality in terms of environmental health: A case study of Siverek (Sanlıurfa). Turkey. Türk Hijyen ve Deneysel Biyoloji Dergisi, 77: 107-120.

[6] Demir Yetis A., Kahraman N., Yesilnacar M.I., Kara H. 2021. Groundwater quality assessment using GIS based on some pollution indicators over the past 10 years (2005-2015): A case study from semi-arid Harran plain, Turkey. Water Air Soil Pollution, 232: 1-17.

[7] Chen Y., Peng C., Wang J., Ye L., Zhang L., Peng Y. 2011. Effect of nitrate recycling ratio on simultaneous biological nutrient removal in a novel anaerobic/anoxic/oxic (A2/O)-biological aerated fitler (BAF) system. Bioresource Technology, 102: 5722-5727.

[8] Erkuş A., Başıüyük M., Erkuş F.Ş. 2015. The examination of paracetamol and diclofenac removal in activated sludge systems under different operating conditions. International Journal of Ecosystems and Ecology Science-IJEES, 5: 315-320.

[9] Saatç1 Y., Özgüven A., Demirci Y. 2007. The Promotion UV Disinfection efficiency in treating secondary effluent by expandedperlite filter. Manas Journal of Natural Sciences, 1 (8), 55-65.

[10] Vaiopoulou E., Aivasidis A. 2008. A modified UCT method for biological nutrient removal: Configuration and performance. Chemosphere, 72: 1062-1068.

[11] Jasim N.A. 2020. The design for wastewater treatment plant (WWTP) with GPS X modelling. Cogent Engineering, 7 (1), 1723782.

[12] Serdarevic A., Dzubur A. 2019. Importance and Practice of Operation and Maintenance of Wastewater Treatment Plants, Proceedings of the International Symposium on Innovative and Interdisciplinary Applications of Advanced Technologies (IAT). Springer Publishing, http://dx.doi. org/10.1007/978-3-030-02577-9 14.

[13] Holloway T.G., Williams J.B., Ouelhadj D., Cleasby B. 2019. Process stress in municipal wastewater treatment processes: A new model for monitoring resilience. Process Safety and Environmental Protection, 132: 169-181.

[14] SKKY, (2004). Su Kirliliği Kontrolü Yönetmeliği, 31.12.2004 Tarih ve 25687 Sayılı Resmi Gazete, Ankara.

[15] Beşkat M.E. 2009. Evsel Atık su Arıtma Tesisleri İşletim Problemleri Siverek Atık su Arıtma Tesisi. Yüksek Lisans Tezi, Harran Üniversitesi, Fen Bilimleri Enstitüsü, Şanlıurfa, 1-85.

[16] Turan, G. 2013. Kentsel Atıksu Arıtma Tesisleri ve İşletme Sorunları. Yüksek Lisans Tezi, Nevşehir Hacı Bektaş Veli Üniversitesi, Fen Bilimleri Enstitüsü, Nevşehir, 1-109.

[17] Baumann P., Krauth KH., Maier W., Roth M. 2012. Operational Problems in Wastewater Treatment Plants. Vol. 3. DWA Landesverband, Stuttgart.

[18] Özalp S., Aydemir B.S., Olgun Ş., Şimşek B., Elmacı H., Evren M., Emre Ö., Aydın M.B., Kurtuluş O., Öcal F., Can A.Z., Yanmaz M.N., Apa R., Duman T.Y. 2016. Van Gölü (Edremit Körfezi) kuvaterner çökellerinde tektonik deformasyonlar. Maden Tetkik ve Arama Dergisi, 153: 45-61.

[19] Yiğit A., İrak Z.T., Öztürk D., Öztürk E., Alpaslan D., Şahan T., Aktaş N. 2017. Van gölü suyunun iyon karakterizasyonuyla su kalitesinin belirlenmesi. Iğdır Üniversitesi Fen Bilimleri Enstitüsü Dergisi, 7 (4): 169-179.

[20] Ozguven, A., Demir Yetis A. 2020. Assessment of spatiotemporal water quality variations, impact analysis and trophic status of big soda lake Van, Turkey. Water, Air, \& Soil Pollution, 231: 1-17.

[21] Demir Yetiş A., Özgüven A. 2020. Van gölü Edremit kıyısı yüzey sularında ağır metal kirliliğinin araştırılması. Uludağ Üniversitesi Mühendislik Fakültesi Dergisi, 25 (2): 831-848.

[22] Anonim, 2011. Edremit Atıksu Arıtma Tesisi Proje Raporu, Van.

[23] Anonim, 2013a. İller Bankası Gevaş Atık Su Arıtma Tesisi Kesin Projesi Açıklama Raporu, Van.

[24] Anonim, 2013b. İller Bankası Başkale Atık Su Arıtma Tesisi Proje Raporu, Van.

[25] Anonim, 2014a. İller Bankası Çelebibağı Atık Su Arıtma Tesisi Poreses Raporu, Van.

[26] Anonim, 2014b. İller Bankası Erçiş Atık Su Arıtma Tesisi ve Kanalizasyon İnşaatı Proje Açıklama Raporu, Van.

[27] Durak A. 2020. Evsel Atık Suların Arıtılmasında Biyolojik Arıtma Yönteminin Uygulanması ve İşletme Sorunlarının İncelenmesi Van İli Örneği. Yüksek Lisans Tezi, Yüzüncü Y1l Üniversitesi, Fen Bilimleri Enstitüsü, Van 1-140.

[28] Türkiye İstatistik Kurumu (TUIK), 2018. Sağlık Kuruluşları Atık İstatistikleri, 18781.

[29] Anonim, 2009. Van Atık Su Arıtma Tesisi Teknik Değerlendirme Raporu, Van. 
[30] Yıldız S., Çekim M. 2016. Paket/Küçük Kapasiteli Atıksu Arıtma Sistemlerindeki İşletme Problemleri ve Çözüm Önerileri. International Symposium of Water and Wastewater Management October 26-28, Malatya. 